\title{
A cross-sectional analysis of the influence of corporate governance features on the organizational outcomes: An assessment
}

\author{
Tariq Tawfeeq Yousif Alabdullah \\ Accounting Department, College of Administration and Economics \\ University of Basrah, Iraq \\ Essia Ries Ahmed \\ Collage of Economics, Management and Information Systems \\ University of Nizwa, Oman
}

\begin{abstract}
This work aimed at testing the influence of corporate governance features on the organizational outcomes in one of the countries of the Gulf Cooperation Council (GCC) which is Qatar. The data was used for the organizations that belong to non-financial sector. The findings revealed that the size of audit commission, the board of directors size, and independency have positive influence on organizational outcomes represented by return on assets. In addition, the same positive influence could be found between the size of the audit commission and independency with return of equity as a second measurement of the organizational outcomes. Moreover, meeting of the board has a significant negative influence on organizational outcomes. The present work is considered as the first study that tests its predictor variables in its relationship with organizational outcomes. The considerable contribution of this study lies in identifying the previous studies gap for the GCC countries and analyses several viable studies that might probably be useful for improving corporate governance system in the non-financial sector.
\end{abstract}

Keywords Corporate governance, audit commission, organizational outcomes, non-financial sector

Paper type Research paper

\section{Introduction}

In developing countries such as countries belonging to the Gulf Cooperation Council, one of significant concerns of Corporate Governance (CG) is disclosure practices and corporate transparency in bringing quality in financial reporting (Aguilera, \& Haxhi, 2019; Alabdullah, 2016b; Alabdullah, 2016a; Claessens, \& Yurtoglu, 2013). In the 16th and 17th centuries, the issue of CG started with the beginning of firm like the East India, Hudson's Bay and Levent (Gevurtz, 2003). Then, corporate governance was

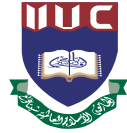

IIUC Studies Vol. 17, Dec. 2020 pp. 9-26 (C) IIUC ISSN 1813-7733 


\section{IIUC Studies, 17}

implemented in the 19th century (Alabdullah, Ahmed, \& Ahmed, 2021; Maroun, \& Cerbone, 2020). Corporate governance is explained as the relationships of legal framework, systems, processes and principle of management control for public and private sectors (Alabdullah, \& Ahmed, 2018; Alabdullah, Ahmed, \& Nor, 2019). In the recent years, attention towards CG has been expanded due to fraud or errors in financial accounting and the reason for this is the shortage of CG regulations and laws in the organizations (Hashim, Ries, \& Huai, 2019). Especially, at the present time, the world is going through a crisis that is considered as one of the most dangerous crises that have passed through the world and led to health, economic and social risks which the world has never encountered before, and this crisis is represented by the Coronavirus pandemic (Alabdullah, Ahmed, \& Nor, 2020; Alabdallah, Ahmed, \& Abushammala, 2020; Alabdullah, \& Ahmed, 2020).

CG in GCC is one of the oldest and most successful experiences in the Arab world (Ahmed, Alabdullah, Thottoli, \& Maryanti, 2020). Also, it is one of the basics of monitoring the path of companies. Therefore, corporate governance is considered as an essential support of the future plan to develop the effectiveness of performance and the rule of law (Al Hosni, Amoudi, \& Callaghan, 2020). Corporate governance is therefore an important tool for the macro-economy both in terms of its growth and promotion (Patel, 2016). Moreover, it is an important system because of its contribution to issuing laws and regulations to organize and manage companies, raising the efficiency of companies to increase the national economy, level of disclosure and transparency (Alabdullah, 2018a; Alabdullah, Nor, \& Ries, 2018). Several countries around the world are suffering from certain problems such as low level of performance, collapse in some large companies, financial scandals and corruption, weak regulatory system, and low level of disclosure and missing transparency. Hence, these problems have affected the global markets in the majority of the GCC countries (Ahmed, Alabdullah, Thottoli, \& Maryanti, 2020).

Based on the above, the practical implications of the current work lies in the analysis undertaken in addressing the gap found in the previous studies of the literature in the GCC organizations and thus it plays a key role for future researchers and studies by regulators and theoreticians. This work ought to analyse and review the different empirical and theoretical contributions to establishing the link between corporate governance and organizational outcomes, especially that the current work is dealing with CG and audit commission and such relationship has its significant role in the 
enhancement of organizational outcomes (firm performance) as confirmed by Dalwai, Basiruddin, and Rasid (2015). This study dealt with the mechanisms of CG because it is considered as an extension of agency theory as mentioned by Alabdullah, Yahya, Nor, and Majeed (2016) and it is therefore considered as a solution or at least an alleviation of agency problem.

Corporate governance has solved many problems, including developing laws and regulations, constantly evaluating performance, developing oversight, measuring resource use, and contributing to risk management evaluation and thus CG has a positive effect on institutional work (Alabdullah, Ahmed, \& Muneerali, 2019). CG seeks to prepare directors and departments to raise productivity of its employees (Chowdhury, Othman, Khan, \& Sulaiman, 2020), the efficiency of companies and transparency in the work environment, oversight and study the problems that make the performance of government and family companies low, raise the national economy and evaluate corporate performance (Alabdullah, Laadjal, Ahmed, \& Al-Asadi, 2018). In addition, organizations seek to develop financial performance of companies to increase profits of companies and their competitiveness in the markets. Some companies suffer from a lack of financial performance due to manipulation of financial statements and fraud, which led to lack of organizational outcomes. This led to a contraction in growth, investments, projects and activities (Abushammala, Alabdullah, \& Ahmed, 2015). In GCC, the governments organized the Capital Market Authority (CMA) with workshops to modernize and improve the corporate governance law (Dry, 2003). Thus, the main purpose of this study is to determine the effect of corporate governance and audit features on organizational outcomes.

\section{Literature review}

Several studies such as Hussain, Rigoni, and Orij (2018) demonstrated that in corporate governance research there is a need for one or more theories. Therefore, our study model is relied on one theory which is agency theory for providing an illustration of the link between management and owners, where the owners and the management are represented by the managers who control and manage companies' resources because the managers have further information than the owners to be used in controlling companies' operations (Jensen \& Meckling, 1976). Nevertheless, because of the knowledge and wide information that the managers have, they strongly might tend to maximize their interests at the account of their owners. 


\section{IIUC Studies, 17}

One of the main objectives of corporate governance system is to run conflicts that could arise between managers and owners. Such a system offers good control over any opportunistic behaviours by managers that may negatively affect minority represented by owners.

The current research focused on the most recent studies related to ccorporate governance and organizational outcomes, specifically on the works done in the last ten years. The current study focused on choosing audit committee/ commission to be as one of the independent variables belonging to CG because it is important to be existing in all non-financial sectors' organizations listed in GCC including Qatar in the non-financial sector and the organizations have to disclose in their annual reports all their financial information in particular forms based on related accepted accounting standards as mentioned by Al Farooque, Buachoom, and Sun (2019). It is to be noted that CG system deals with the setup tools that the forms, actions and activities are managed, to maximizing principal value via the duty of directors and enhance firm's performance (Ahmed, Alabdullah, Shaharudin, \& Putri, 2020; Alabdullah, 2018). Ahmed, Alabdullah, Thottoli, and Maryanti (2020) in their study focused on testing the relation between CG tools and firms' performance in GCC companies. This study indicated that a positive relation among all predictors is found: ownership, board size, audit commission, gender and firm financial performance. Al Ani and $\mathrm{Al}$ Kathiri (2019) study the troubled environment and its impacts on the corporate performance of industrial companies. The troubled environment is measured by growth of sales, while financial work is measured by net profits and return on property rights. The study found positive effects between the troubled environment and its financial performance. Yilmaz (2018) attempts to test the link between CG and corporate performance in GCC. It uses 61 companies listed on the MSM from 2013 to 2016. The study used two indicators, namely market-based and accounting-based indicators as independent variables. Tobin's $Q$ is used to evaluate the market work. It also used ROA, gross profit margin, net profit margin and EBIT margin to evaluate accounting-based indicators. This study clarifies that there are significant outcomes among financial ratios and features of CG. Bilal, Twafik, and Bakhit (2018) tested the effect of audit on CG in commercial banks in one of GCC countries, where information and data were collected and collected through a questionnaire distributed to 100 senior officials and the internal audit of the Commercial Banking Department. This study includes five variables: independence of internal audit, competence and professional care, nature of work, quality assurance, developed program and 
management of the internal audit activity. The research demonstrated a positive link among internal audit and effective CG. There is also an important relationship among the independence and efficiency of professional care reviews and the nature of work in corporate governance in quality assurance, program strengthening and internal audit activities. Aktan, Turen, Tvaronavičiene, Celik, and Alsadeh (2018) test the link among CG and its work in the Bahrain, where this study uses all the data of companies listed on the Bahrain Stock Exchange, and the results showed that the size of the directors board, the auditor's reputation and the concentration of ownership have a positive effect on the return of firms. Kakanda, and Salim (2017) tested the link among CG, risk management, and corporate work by proposing a research agenda. It collects data on board characteristics (board composition, board size, board expertise and board meeting) and it collects data on risk management from files. The outcomes for this research found that the link between board features and risk management disclosure with corporate work was of positive importance. Abdallah and Ismail (2017) study the link between governance quality and corporate performance in GCC. This research was funded by the concentrated ownership and government share, where the results expect no harmony or consistency in the quality of governance through exchanges, as it was found that the link is positive among the governance quality and the work of the company. Al-Matari, Al-Matari, and Saif (2017) reported the impact of focus and ownership on the work of the company ROA in the GCC for the years 2010-2014 among non-financial companies; the goal of this study is to explore the influence of quality audit on ownership and the relationship of ownership work of the company, led to the difference among the structure and regulations among the two sectors from 2012 to 2014, which led to a focus on the non-financial sector. This study indicates that the concentration of ownership has an important impact on the return on assets. The study failed to find an appropriate impact on the quality of audit of the link among ownership, administrative ownership, and corporate work. Buallay, Hamdan, and Zureigat (2017) attempt to measure the effect of CG on the work of listed firms, the data was collected from the SSE for the period between 2012 and 2014 including 161 listed firms. The independent variable of the study is the principles of CG, while the dependent variable is the fixed work that was measured by ROE, ROA, and Tobin's Q. The study used five variables to measure the link between CG and fixed performance. The level of corporate governance in Kingdom of Saudi Arabia was 61.4\% which was high; information indicates that there is no impact on the adoption of CG for the 


\section{IIUC Studies, 17}

financial and operational work of the company and also the lack of significant impact on shareholder ownership and board independence management on performance of the company. Badhabi (2016) tests the impact of audit commission on disclosure quality of the financial reporting for the MSM companies for the years 2014-2015. This study explains the impact of the features of the audit commission: strategy of multi-management, size, independence, meeting, chief independence, diligence and consistent performance. The process of collecting and investigating secondary data was through annual financial reports of companies collected by data stream. The outcomes of this research showed that the features of the audit commission do not impact the work of firm. It also showed that the size of the firm and the leverage have a major effect on the firms work. This research suggests for future consideration in conducting studies of some variables like the members of the foreign audit commission and its role in improving the company's performance. Al-Matari (2014) investigated the impact of CG mechanisms (characteristics of directors board, auditing, executive committee) on the companies performance measured by Return on Assets (ROA) and Tobin's Q. It was found by them that the executive committee existence and audit commission meeting were negative determinants of Tobin's Q while board meeting, board size and time period (2010) were positive factors of Tobin's Q. This study points to a theory of resource dependency more compared to agency theory when describing. Al-Najjar (2014) studies the link between CG and performance in tourism firms. It uses variable models through 2SLS for public listed firms in the Middle East. The study indicates the independence of board of directors with firm performance and stock performance. Therefore, members of the board of directors are independent, which tend to the development of firms' overall performance. Al-Matari, Al-Swidi, and Fadzil (2014a) in their analysis try to explain the link between two significant groups of CG, which are audit features and executive features and performance. The main objective of this research is to connect between CG and performance. Therefore, this study is an aim to take new measures and help with a rich set of research. The results for this study found that the link among firm size and performance was of positive significance, while the link among leverage and performance was of negative importance. Otman (2014) analyzed the effects of tools of corporate governance on firm performance in the Middle East and North Africa (MENA) region. They mentioned that the financial disclosures and corruption in companies in many countries have led to good interest in CG, performance and organization. The influence of CG on corporate work 
varies based on several social and cultural factors (Ahmad, Khan, Abdullah, \& Rashid, 2017). The foundations of CG are useful and fair treatment of shareholders, the role of stakeholders in CG, disclosure, and boardroom responsibilities. This study uses the agency and stakeholder theories, and a questionnaire was used to analyze data on corporate governance in the UAE, where the results of this questionnaire indicated that CG is significant for all beneficiaries. Al-Matari, Fadzil, and Al-Swidi (2014) tested the link among the features of the audit commission and the work of the GCC organizations. The study tries to obtain the moderate effect of the board diversity on the association among firm performance and audit commission. Also, this study revealed the impact of foreign board members on the independence of the audit board and performance. Moreover, the study provides some future recommendations. Fallatah and Dickins (2012) in their study test the link among the characteristics of CG, its performance and its value using an indicator indicating the capture of the common effect of CG governance characteristics. The importance of the Saudi Arabia state as an international market for investment is affected by governance and percentages of internal ownership. CG and its work are measured by the ROA, CG and its value measured by Tobin's Q. Brown and Caylor (2009) revealed the provisions of CG for the operating work of the company, seven provisions that relate positively to the return on assets using three criteria, ten provisions of CG are positively linked to the ROA, nine of which were linked to the assignment of stock exchanges, the committee consists of independent external managers, which are positively linked to the operating performance of the company, CG reforms imposed by the three exchanges in the United States are not closely related to operating performance. Al Ani and Mohammed (2015) investigated the influence of auditor and quality on the company's work. The quality of the auditor is measured by a large or not large audit company. Profit is measured through ROE and ROA, while performance is measured at market fair value and risk is measured by leverage. Based on the previous studies done in Middle east, the area of corporate governance still needs improvement. Alternatively, new trends and directions in the business operations have given consideration to the Islamic financial industry due to the financial crises as a substitute choice through using Islamic financial tools based on the real economy (Ahmed, Islam, Zuqibeh, \& Alabdullah, 2014; Ahmed, Islam, \& Alabdullah, 2018; Ahmed, Alabdullah, Islam, \& Asmar. 2014; Ahmed, Amran, \& Islam, 2018; Ahmed, Islam, Alabdullah, \& Amran, 2019; Ahmed, Islam, Alabdullah, \& bin Amran, 2018). 


\section{IIUC Studies, 17}

Based on the argument in the literature review, we predict the following set of hypotheses:

H1: There is a positive link between Board Size and organizational outcomes represented by ROA and ROE.

H2: There is a positive link between Independency in the board and organizational outcomes represented by ROA and ROE.

H3: There is a positive link between Board meeting and organizational outcomes represented by ROA and ROE.

H4: There is a positive link between audit commission size and organizational outcomes represented by ROA and ROE.

H5: There is a positive link between audit commission independence size and organizational outcomes represented by ROA and ROE.

H6: There is a positive link between audit commission meeting and organizational outcomes represented by ROA and ROE.

\section{Methodology}

The population of the current work is represented by 40 public listed organizations in one of the countries belonging to GCC which is Qatar. The sources of data collection used by the current work depended on hand collected data from annual reports. The current study is a cross-sectional on based on quantitative approach and the data collected was from annual reports. The units of analysis were the annual reports of the listed organizations for 2019. Yearly reports were widely used to examine the organizational outcomes that reflect the firm performance. Data was analysed statistically via using the Microsoft Excel and Partial Least Square (PLS) approach.

Variables measurements: The current work used a wide range of measurements of corporate governance tools, audit commission features and organizational outcomes. Each variable is illustrated as follows:

Table 1: Variables measurement

\begin{tabular}{lll}
\hline Independent Variables & Acronym & \multicolumn{1}{c}{ Description } \\
\hline Return on assets & ROA & Net income after taxes / total assets \\
Return on equity & ROE & Net income after Taxes / total equity \\
Board Size & BOD-Z & The numbers of Male and Female in the board \\
In-dependency & BOD-IND & Number of Independent managers in the Board of Directors \\
Board meeting & BOD-MEET & Number of board meetings \\
Audit commission size & AUD -Z & Number of the members of audit Commission \\
Audit commission independence & AUD-IND & Number of the members independent audit commission \\
\hline Audit commission meeting & AUD-CO-M & Number of audit commission meetings in 2019 \\
\hline
\end{tabular}


Models of the study:

The models of the current work are represented by a set of specific variables, with the board features affecting organizational outcomes. Such variables could affect the organizational outcomes represented by ROA and ROE. The models that we used in the current study are defined below:

$$
\begin{aligned}
& R O A=\alpha+\beta_{1} B S+\beta_{2} B I+\beta_{3} B M+\beta_{4} A C S+\beta_{5} A C I+\beta_{6} A C M \varepsilon \\
& R O E=\alpha+\beta_{1} B S+\beta_{2} B I+\beta_{3} B M+\beta_{4} A C S+\beta_{5} A C I+\beta_{6} A C M \varepsilon
\end{aligned}
$$

Noting that the justification of using PLS by the current study is that because PLS accepts small size of organizations in analysing the data without a negative impact on the soundness of the results, it is not for example like SPSS program that doesn't accept small sample size.

\section{Results}

\subsection{Descriptive statistics}

Based on the results of descriptive analyses, the dependent variable, which is organizational outcomes (ROA and ROE), shows that ROA level was $12 \%$ representing the average of organizational outcomes, with a standard deviation (ST.D) of 0.0590 . Moreover, the minimum and maximum values indicated that ROA is $25 \%$ and $12 \%$, respectively. Also the results revealed that ROE level was $20 \%$ representing the average of organizational outcomes, with a ST.D of 0.013 . Besides, the minimum and maximum values indicated that ROE is $34 \%$ and $26 \%$, respectively. In addition, the descriptive analysis for determinants shows that audit commission meeting has an average of $4.18 \%$ with standard deviation of 1.600 ; the board size has an average of $6.90 \%$ with ST.D of 1.590 ; the board meeting has an average of $6.15 \%$ with ST.D of 1.480 ; the audit size has an average of $3.45 \%$ with ST.D of 0.569 ; the audit independence has an average of $0.56 \%$ with ST.D of 0.159; the board independence has an average of $0.59 \%$ with ST.D of 0.155 .

Table 2: Descriptive Statistics

\begin{tabular}{lcccr}
\hline & Mean & Min & Max & Standard-D \\
\hline ROA & 0.0120 & -0.2500 & 0.1290 & 0.0590 \\
ROE & 0.0200 & -0.3410 & 0.2650 & 0.1440 \\
BOD-Z & 6.9000 & 5.0000 & 12.000 & 1.4850 \\
BOD-MEET & 6.1570 & 5.0000 & 9.0000 & 1.5690 \\
BOD-IND & 0.6820 & 0.2600 & 2.0000 & 0.1550 \\
AUD -Z & 3.4530 & 3.2000 & 5.2000 & 0.5690 \\
AUD-IND & 0.5670 & 0.2900 & 1.1000 & 0.1590 \\
AUD-CO-M & 4.1870 & 3.0000 & 9.000 & 1.6030
\end{tabular}


4.2. Discriminant validity

In PLS for testing the discriminant validity, there are standards applied. The square-root of every AVE for every construct must have a high correlation level including other constructs. Thus, to deal with the square root, discriminant validity of each construct in its AVE has to be compared versus the constructs' correlations for all other constructs.

Table 3: Discriminant Validity Constructs

\begin{tabular}{lrlllllll}
\hline & ROA & ROE & BOD-Z BOD-MEET BOD-IND AUD -Z AUD-IND AUD-CO-M \\
\hline ROA & 1.0000 & & & & & & \\
ROE & 0.8420 & 1.0000 & & & & & \\
BOD-Z & 0.0940 & 0.0890 & 1.0000 & & & & & \\
BOD-MEET & -0.1930 & -0.1680 & 0.2990 & 1.0000 & & & & \\
BOD-IND & 0.1120 & 0.1650 & 0.0310 & -0.0820 & 1.0000 & & & \\
AUD -Z & 0.0810 & 0.0720 & 0.2770 & 0.4770 & -0.2510 & 1.0000 & & \\
AUD-IND & -0.0660 & -0.0880 & -0.1870 & -0.0590 & 0.4720 & -0.1370 & 1.0000 & \\
AUD-CO-M & -0.2220 & -0.1530 & 0.3030 & 0.5720 & -0.0790 & 0.3410 & -0.2200 & 1.0000 \\
\hline
\end{tabular}

Evaluation for the Structural-model was done after analysis of measurement model and it has passed all criteria. An examination of the determination coefficient $\left(\mathrm{R}^{2}\right)$ is done. In this work, the dependent variables of the current study show that $\mathrm{R}^{2}$ value 0.13 (ROA), 0.14 (ROE) (substantial) suggesting that $12 \%, 15 \%$ of the variance in firm performance (ROA and $\mathrm{ROE}$ ) can be clarified by independent variables: board of directors (board meeting, board size and independence of board) and audit commission (audit size, audit meeting and audit independence). Thus, the current work highly meets the criteria.

Table 4: Explanation of Variance

\begin{tabular}{lr}
\hline Variables & R Square \\
\hline Exogenous Variables -> Endogenous (ROA) & 0.134 \\
Exogenous Variables -> Endogenous (ROE) & 0.141
\end{tabular}

\subsection{Hypothesis testing}

Table 5, reviews the results related to testing the hypothesis and found majority of the hypotheses are not supported (Only four hypotheses supported as shown in table 5). The findings revealed that there is a significant and positive link among audit size and organization outcomes (ROE) where it was $\mathrm{P}<0.05, \mathrm{t}=0.281$. This result indicates that audit size has a significant effect on FP (ROE). The results showed that board 
independence has a significant positive link with organization outcomes (ROE) where it was $\mathrm{P}<0.05, \mathrm{t}=0.316$. This result shows that in-dependency has a significant impact on organization outcomes (ROE). The findings showed that board meeting is negatively significant with organization outcomes (ROE) where it was $\mathrm{P}<0.05, \mathrm{t}=-0.249$. This result indicates that the board meeting has a significant effect on organization outcomes (ROE).

Table 5: Path Coefficients

\begin{tabular}{|c|c|c|c|}
\hline Variables & Path Coefficients & $\mathrm{t}$-value & Supported \\
\hline BOD-Z - <ROA & 0.100 & 0.534 & $\mathrm{NO}$ \\
\hline BOD-Z - <ROE & 0.032 & 0.217 & $\mathrm{NO}$ \\
\hline BOD-MEET - $<$ ROA & -0.230 & 0.819 & $\mathrm{NO}$ \\
\hline BOD-MEET - <ROE & -0.249 & $1.418^{*}$ & YES \\
\hline BOD-IND $-<$ ROA & 0.166 & 0.980 & $\mathrm{NO}$ \\
\hline BOD-IND $-<$ ROE & 0.316 & $1.763^{*}$ & YES \\
\hline AUD $-\mathrm{Z}-<\mathrm{ROA}$ & 0.240 & $1.476^{*}$ & YES \\
\hline AUD -Z - <ROE & 0.281 & $1.645^{*}$ & YES \\
\hline AUD-CO-MEET - <ROA & -0.179 & 0.820 & $\mathrm{NO}$ \\
\hline AUD-CO-MEET - <ROE & -0.063 & 0.288 & $\mathrm{NO}$ \\
\hline AUD-IND - <ROA & -0.095 & 0.345 & $\mathrm{NO}$ \\
\hline AUD-IND - <ROE & -0.213 & 0.979 & $\mathrm{NO}$ \\
\hline
\end{tabular}

Note: Significance levels: ${ }^{* * *} \mathrm{P}<0.001(\mathrm{t}>3.33),{ }^{* *} \mathrm{p}<0.01(\mathrm{t}>2.33),{ }^{*} \mathrm{p}<0.05(\mathrm{t}>1.605)$

\section{Discussion and conclusion}

The study investigates the effects of CG and features of audit commission on organization outcomes in Qatar. Therefore, the research aims to analyse and understand the effect of CG and organization outcomes. This research determines six variables that influence organization outcomes; these are the independent variables which are the board of directors (board meeting, board size and independency of the board) and audit commission (audit size, audit meeting and audit independence). From all independent variables that are identified, hypotheses were formed to inquire about the objective. The findings of this study revealed that not all the hypotheses are significant (only four hypotheses have significant relationship with organization outcomes). It is audit size with (ROA and ROE), board independence with (ROE) and board committee meeting with (ROE). One of the independent variables associated with CG and organization outcomes is the board meeting. The findings show a significant and negative link between board meeting and organization outcomes $(\mathrm{p}<0.05, \mathrm{t}=1.418)$. The result is consistent with the 
findings of study done by Al-Matari (2014). He mentioned that councils must be relatively inactive, that is, the meetings number is few. The higher number of meeting activity indicates a response to poor organization outcomes in order to develop organization outcomes in the coming years. However, some previous studies found a positive relationship between the board meeting and organization outcomes.

Also, the results show a positive significant link between the board in-dependence and organization outcomes $(\mathrm{p}<0.05, \mathrm{t}=1.763)$. This result is consistent with the previous study done by Al-Najjar (2014). This indicates the importance of board independence to improve the organization outcomes. Audit size is a key component of the quality of the audit features. It is measured by a number of the people serving on the audit commission of the company (Nuryanah, \& Islam, 2011). Findings show a positive and significant link between audit size and organization outcomes $(\mathrm{P}<0.05$, $\mathrm{t}=1.645)$ with $\mathrm{ROE}$ and $(\mathrm{P}<0.05, \mathrm{t}=1.476)$ with $\mathrm{ROA}$. This means that $\mathrm{H} 4$ is supported. This fact shows that the higher audit size, the higher organization outcomes of Qatar organizations. This reveals that the audit commission applied good CG mechanisms. The findings of this study are not consistent with the studies done by Ahmed, Alabdullah, and Shaharudin (2020) and Al-Matari, Al-Swidi, and Fadzil (2014). However, some studies in developed countries indicate a significant link between audit size and organization outcomes.

Besides, the originality and value of this study lies in identifying the previous studies gap for the GCC countries and analyses several viable studies that might probably be useful for improving corporate governance in the non-financial sector. This study would introduce great opportunities for those who are willing to write papers in the study area and discipline.

\section{Recommendations, implications, and limitations}

For the research limitations/implications, the available studies are usable for the region under study, and the findings require not be usable for other environments. Moreover, the development of economic environment has constantly led to incompatible results; therefore, the time period of research can mostly introduce varied results, where the practical implications in the current study revealed that analysis conducted addressed the gaps in previous studies for the GCC non-financial sector, particularly in Qatar, as it plays an important role for future studies in this environment by scholars and theorists.

The study tests the relationship between CG and audit characteristics on 
corporate performance. There are no enough studies that examines the impact of other variables on the link between CG and its performance such as diversity of the board, quality of review and culture that would lead to help in enhancing performance. The study suggests for future researchers to test the link between CG and its work through other theories such as supervision, stakeholder and transaction cost theory. The future scholars must look into the link between CG and its work in depth by adding new independent variables like board commitment and reward for attendance. Future researchers must expand the organizational outcomes to agent and integrate accounting measurements that would lead to influential outcomes. The conducting of integrated research among the directors board, audit commission, the executive committee, and the ownership structure promotes practices of corporate governance.

For the limitations of the research, data collection is only for one year which is 2019 and this period is short and does not reflect all the operations of the sample companies. Therefore, we recommend the future research to do panel data study via using the same variables used by the current study with five or more than five years. Moreover, the study focuses only on six independent variables and two dependent ones, while there are other variables that affect the performance of companies.

\section{References}

Abdallah, A. A. N., \& Ismail, A. K. (2017). Corporate governance practices, ownership structure, and corporate performance in the GCC countries. Journal of International Financial Markets, Institutions and Money, 46, 98-115.

Abushammala, S. N., Alabdullah, T. T. Y., \& Ahmed, E. R. (2015). Causal relationship between market growth and economic growth: Comparison study. European Journal of Business and Management, 7(33), 31-36.

Aguilera, R. V., \& Haxhi, I. (2019). Comparative corporate governance in emerging markets. The Oxford Handbook of Management in Emerging Markets, 185-210.

Ahmad, A., Khan, M. A., Abdullah, A. A. M., \& Rashid, M. H. U. (2017). Environmental disclosures: A study on some selected pharmaceutical and chemical companies in Bangladesh. IIUC Business Review, 6, 9-24.

Ahmed, E. R., Alabdullah, T. T. Y., \& Shaharudin, M. S. (2020). Approaches to control mechanisms and their implications for companies' profitability: A study in UAE. Journal of Accounting Science, 4(2), 11-20. 
Ahmed, E. R., Alabdullah, T. T. Y., Shaharudin, M. S., \& Putri, E. (2020). Further evidence on the link between firm's control mechanisms and firm financial performance: Sultanate of Oman. Journal of Governance and Integrity, 4(1), 1-6.

Ahmed, E. R., Alabdullah, T. T. Y., Thottoli, M. M., \& Maryanti, E. (2020). Does corporate governance predict firm profitability? An empirical study in Oman. The International Journal of Accounting and Business Society, 28(1), 127-143.

Ahmed, E. R., Alabdullah, T. Y., Islam, M. A., \& Asmar, M. (2014, June 4-6). Sukuk legitimacy: A new measurement based on content analysis. Paper presented at the 16th Malaysian Finance Association Conference in Sasana Kijang Central Bank of Malaysia, Kuala Lumpur.

Ahmed, E. R., Amran, A., \& Islam, M. A. (2018). Sukuk documentation and legitimacy: The role of Shariah supervisory board as a moderator. Management, 5, 22-40.

Ahmed, E. R., Islam, A., Alabdullah, T. T. Y., \& Amran, A (2019). A qualitative analysis on the determinants of legitimacy of Sukuk. Journal of Islamic Accounting and Business Research,10(3), 342-368.

Ahmed, E. R., Islam, A., Zuqibeh, A., \& Alabdullah, T. T. Y. (2014). Risks management in Islamic financial instruments. Advances in Environmental Biology, 8(9), 402-406.

Ahmed, E. R., Islam, M. A., \& Alabdullah, T. T. Y. (2018). The moderating role of Shariah supervisory board on sukuk pricing benchmark. International Journal of Excellence in Islamic Banking and Finance, 6(2), 1-32.

Ahmed, E. R., Islam, M. A., Alabdullah, T. T. Y., \& Bin Amran, A. (2018). Proposed the pricing model as an alternative Islamic benchmark. Benchmarking: An International Journal, 25(8), 2892-2912.

Aktan, B., Turen, S., Tvaronavičiene, M., Celik, S., \& Alsadeh, H. A. (2018). Corporate governance and performance of the financial firms in Bahrain. Polish Journal of Management Studies, 17(1), 39-58.

Al Ani, M. K., \& Al Kathiri, M. S. (2019). The impact of turbulent environment on firm performance: A study on Omani industrial companies. IUP Journal of Applied Finance, 25(1), 7-20.

Al Ani, M. K., \& Mohammed, Z. O. (2015). Auditor quality and firm performance: Omani experience. European Journal of Economics, Finance and Administrative Sciences, 74, 13-23. 
Al Farooque, O., Buachoom, W., \& Sun, L. (2019). Board, audit committee, ownership and financial performance-emerging trends from Thailand. Pacific Accounting Review, 32(1), 54-81.

Al Hosni, I. S., Amoudi, O., \& Callaghan, N. (2020). An exploratory study on challenges of circular economy in the built environment in Oman. Proceedings of the Institution of Civil Engineers-Management, Procurement and Law, 173(3), 104-113.

Alabdullah, T. T. Y. \& Ahmed, E. R. (2018). Corporate Governance: To what extent it is important in the Arab countries? International Journal of Science and Research, 7(11), 673-679.

Alabdullah, T. T. Y. (2016a). Corporate governance from the perspective of the past and the present and the need to fill an international gap. Risk Governance \& Control: Financial Markets \& Institutions, 6, 96-101.

Alabdullah, T. T. Y. (2016b). The performance of companies and the board's characteristics from the new perspective of manipulation avoidance. Corporate Ownership \& Control, 13, 279-286.

Alabdullah, T. T. Y. (2018). The relationship between ownership structure and firm financial performance: Evidence from Jordan. Benchmarking: An International Journal, 25, 319-333.

Alabdullah, T. T. Y., \& Ahmed, E. R. (2020). Audit committee impact on corporate profitability in Oman companies: An auditing and management accounting perspective. JURNAL Riset Akuntansi dan Keuangan Indonesia, 4(2), 121-128.

Alabdullah, T. T. Y., Ahmed, E. R., \& Abushammala, S. (2020). Growth of companies: Empirical study of the companies listed in developing economies. Journal of Accounting Science, 4(2), 1-10.

Alabdullah, T. T. Y., Ahmed, E. R., \& Ahmed, R. R. (2021). Organization features and profitability: Implications for a sample of emerging countries. Journal of Accounting and Business Education (JABE), 5(2), 43-52.

Alabdullah, T. T. Y., Ahmed, E. R., \& Muneerali, M. (2019). Effect of board size and duality on corporate social responsibility: What has improved in corporate governance in Asia? Journal of Accounting Science, 3(2), 121-135.

Alabdullah, T. T. Y., Ahmed, E. R., \& Nor, M. I. (2019). Do board characteristics provide more enhancement for firm financial performance? A corporate governance perspective. New Challenges in Corporate Governance: Theory and Practice, 4(3),89-91. 
Alabdullah, T. T. Y., Ahmed, E. R., \& Nor, M. I. (2020). The world declining economy and coronavirus pandemic: Systems should be continued. Russian Journal of Agricultural and Socio-Economic Sciences, 102(6), 89-96.

Alabdullah, T. T. Y., Laadjal, A., Ahmed, E. R., \& Al-Asadi, Y. A. A. (2018). Board features and capital structure in emerging markets. Journal of Advanced Management Science, 6(2), 74-80.

Alabdullah, T. T. Y., Nor, M. I., \& E. Ries (2018). The determination of firm performance in emerging nations: Do board size and firm size matter. Management, 5, 57-66.

Alabdullah, T. T. Y., Yahya, S., \& Ramayah, T. (2014). Corporate governance development: New or old concept? European Journal of Business and Management, 6(7), 312-315.

Alabdullah, T. T. Y., Yahya, S., Nor, M., \& Majeed, F. (2016). An investigation of corporate governance from a new perspective: Examining the financial performance of companies and the impact of executive turnover. Corporate Board: Role, Duties \& Composition, 12(1), 53-67.

Al-Matari, E. M. A. (2014). Corporate governance and performance of non-financial public listed firms in Oman. Unpublished PhD Dissertation: Universiti Utara Malaysia, Malaysia.

Al-Matari, E. M., Al-Matari, Y. A., \& Saif, S. A. (2017). Ownership structure, audit quality and firm performance moderating and direct-effect models: An empirical study. Corporate Board: Role, Duties and Composition, 13(1), 28-35.

Al-Matari, E. M., Al-Swidi, A. K., \& Fadzil, F. H. B. (2014). Audit committee characteristics and executive committee characteristics and firm performance in Oman: Empirical study. Asian Social Science, 10(12), 98.

Al-Matari, E. M., Fadzil, F. H., \& Al-Swidi, A. K. (2014). The moderating effect of board diversity on the relationship between audit committee characteristics and firm performance in Oman: Empirical study. Middle East Journal of Scientific Research, 21(5), 792-801.

Al-Najjar, B. (2014). Corporate governance, tourism growth and firm performance: Evidence from publicly listed tourism firms in five Middle Eastern countries. Tourism Management, 42, 342-351.

Badhabi, H. A. S. (2016). The influence of audit committee characteristics on firm performance: Evidence in Oman. Unpublished $\mathrm{PhD}$ Dissertation: Universiti Utara Malaysia, Malaysia. 
Badhabi, H. A. S. (2016). The influence of audit committee characteristics on firm performance: Evidence in Oman. Unpublished PhD Dissertation: Universiti Utara Malaysia, Malaysia.

Bilal, Z. O., Twafik, O. I., \& Bakhit, A. K. (2018). The influence of internal auditing on effective corporate governance in the banking sector in Oman. European Scientific Journal, 18, 257-271.

Brown, L. D., \& Caylor, M. L. (2009). Corporate governance and firm operating performance. Review of Quantitative Finance and Accounting, 32(2), 129-144.

Buallay, A., Hamdan, A., \& Zureigat, Q. (2017). Corporate governance and firm performance: Evidence from Saudi Arabia. Australasian Accounting, Business and Finance Journal, 11(1), 78-98.

Chowdhury, M. M. I., Othman, K. B., Khan, M. A., \& Sulaiman, I. F. (2020). Role of effective corporate governance and motivational leadership in increasing productivity and efficiency of human resources. Global Journal of Management and Business Research, 20(10), 29-39.

Claessens, S., \& Yurtoglu, B. B. (2013). Corporate governance in emerging markets: A survey. Emerging Markets Review, 15, 1-33.

Dalwai, T. A. R., Basiruddin, R., \& Rasid, S. Z. A. (2015). A critical review of relationship between corporate governance and firm performance: GCC banking sector perspective. Corporate Governance, 15(1), 18-30.

Dry, E. K. (2003). Corporate governance in the Sultanate of Oman. Rich. J. Global L. \& Bus., 3, 45.

Fallatah, Y., \& Dickins, D. (2012). Corporate governance and firm performance and value in Saudi Arabia. African Journal of Business Management, 6(36), 10025-10034.

Gevurtz, F. A. (2003). The European origins and the spread of the corporate board of directors. Stetson L. Rev., 33, 925.

Hashim, F., Ries, E. A., \& Huai, N. T. (2019). Corporate social responsibility and financial performance: The case of Asian telecommunications companies. KnE Social Sciences, 1, 892-913.

Hussain, N., Rigoni, U. \& Orij, R. P. (2018). Corporate governance and sustainability performance: Analysis of triple bottom line performance. Journal of Business Ethics, 149(2), 411-432.

Jensen, M., \& Meckling, W. H. (1976). Theory of the firm: Managerial behaviour, agency costs and ownership structure. Journal of Financial Economics, 3(4), 305-360. 
Kakanda, M. M., \& Salim, B. (2017). Corporate governance, risk management disclosure, and firm performance: A theoretical and empirical review perspective. Asian Economic and Financial Review, 7(9), 836.

Maroun, W., \& Cerbone, D. (2020). Corporate Governance in South Africa (Vol. 2). German: Walter de Gruyter GmbH \& Co KG.

Nuryanah, S., \& Islam, S. M. (2011). Corporate governance and performance: Evidence from an emerging market. Management \& Accounting Review, 10(1), 17-42.

Otman, K. A. M. (2014). Corporate governance and firm performance in listed companies in the United Arab Emirates. Unpublished PhD Dissertation: Victoria University, United Arab Emirates.

Patel, A. D, (2016). Oman: New code of corporate governance for publicly listed companies comes into force. United Kingdom: Euromoney Institutional Investor PLC.

Yilmaz, I. (2018). Corporate governance and financial performance relationship: Case for Oman companies. Journal of Accounting, Finance and Auditing Studies, 4(4), 84-106.

\section{Corresponding author}

Essia Ries Ahmed can be contacted at: e.ahmed@unizwa.edu.om 